\title{
When Neoliberalism Confronts the Moral Economy of Workers: The Final Spring of Turkish Labor Unions
}

Mustafa G. Dogan

\section{(2) OpenEdition \\ Journals}

Electronic version

URL: http://journals.openedition.org/ejts/4321

DOI: 10.4000/ejts.4321

ISSN: $1773-0546$

Publisher

EJTS

\section{Electronic reference}

Mustafa G. Dogan, «When Neoliberalism Confronts the Moral Economy of Workers: The Final Spring of Turkish Labor Unions », European Journal of Turkish Studies [Online], 11 | 2010, Online since 21 October 2010, connection on 10 December 2020. URL : http://journals.openedition.org/ejts/4321 ; DOI : https://doi.org/10.4000/ejts.4321

This text was automatically generated on 10 December 2020 .

(c) Some rights reserved / Creative Commons license 


\title{
When Neoliberalism Confronts the Moral Economy of Workers: The Final Spring of Turkish Labor Unions
}

\author{
Mustafa G. Dogan
}

\section{Introduction}

1 The economic package proclaimed in Turkey on 24 January 1980 and the ensuing military coup, which made possible the implementation of the package by bulldozing the existing social and political configuration of the country, restructured the Turkish regime and the state apparatus throughout the following decades. Presently, it is a well established tendency to trace the demise of class-based popular opposition back to the 1980 coup d'État. From a comparative perspective Turkey is not unique in witnessing the rise of the free-economy/strong-state type of politics known as neo-conservatism to the detriment of populist regimes based on protectionist economic policies and national developmental goals. The regimes of the Southern Cone in Latin America that survived coups in the early seventies had more or less comparable experiences (Schamis 1991). However, such developments were not limited to fragile democracies. For instance, in the United Kingdom a thorough transformation was also realized, though through a different form of authoritarianism (Jessop et al. 1984). In these more entrenched democracies, where labor unions were far more powerful, governments preferred more vigilant policing of social protest to outright military interventions.

2 These global developments are related to the politics of creating or restructuring markets. Such political and social transformations are largely results of deliberate political acts, as illustrated by the literature on the social embeddedness of market structures (Granovetter 1985). Neo-conservative governments, whether they were outright military regimes like the one in Chile or respected and well-established 
polyarchies such as Thatcherite Great Britain, can be analyzed as different cases of restructuring society at large according to the needs of a changing accumulation regime and corresponding mode of articulation to the global economy. The politics of market-making usually refers to institution-building through politics. However, it also involves destroying existing institutions by whatever means necessary in order to clear space for new ones. In most the Third World settings, this means deliberately destroying the populist vestiges of the old regimes and some aspects of participatory democracy.

With its neoliberal emphasis on replacing the entrenched developmentalist and populist mode of operation in state economic enterprises with market rationality and profit-maximizing behavior, the Özal administration of the 1980s targeted the moral economy of the public enterprise workers, and hence the very foundation of the Turkish organized labor movement. Such policies are not unique to Turkey; indeed they were the basic tenets of structural adjustment programs that international financial organizations promoted in indebted third-world countries. In many countries protest movements with differing motives and actors developed in opposition to these measures and attained varying results. In the Turkish case the main actor was organized labor, and the main target was what it perceived as an assault on the moral economy of the unionized workers. However, the lively protest movement that contributed to the defeat of the Motherland Party [Anavatan Partisi (ANAP)] at the polls in the 1989 municipal elections and in the general elections two years later is often overlooked. This paper intends to shed light on this cycle of protest by first exposing the basic tenets of Turkish labor unionism, then exploring the moral economy argument, and lastly describing the development of the cycle of protest spanning from the end of 1986 to the final days of 1991.

\section{Labor unions in Turkey}

4 From 1908 onwards, political opportunity structures stimulated unionization efforts among Turkish workers. This is one of the defining traits of the Turkish organized labor movement; workplace activists have always tried to benefit from opportune situations and established local hubs of activity at the grassroots level. The first wave of strikes, for instance, took place immediately after the reinstitution of the constitutional rights of Ottoman citizens in 1908, and the first labor unions were established immediately after the removal of the ban on class-based societies in 1946. These developments confirm the claims of the "political process" approach to social movements, which argues that favorable political opportunity structures, such as a political cleavage among traditional elites that weakens the political pressure on subordinated sectors of society, contribute to the initiation of the social movements and protests (Tarrow et al. 2006: 45-68).

5 Turkish labor historians are inclined to search for historical precedents. Whenever confronted with an innovative protest action they look for earlier instances of strikes or unionization activities. However, unless it is assumed that working classes are submissive by definition, there in no reason to be surprised by spontaneous protest movements. Whenever proper conditions are met, people tend to act collectively to ameliorate their social, economic and political position, using tried-and-true routines or importing routines from different domains of social experience. All in all, laborers 
both in the Ottoman and republican eras resisted the transformation brought by capitalist relations of production, either by relying on their already existing tool kit of protest or by adapting parts of it to the new situation.

6 Governments often try to balance their developmental needs with attempts to control the industrialization process and delimit its consequences. Turkish governments, both in the one-party and multi-party era, are no exceptions. As illustrated by the Labor Code of 1936, Ankara was always reluctant to recognize the collective rights of workers, preferring instead to bestow individual protection through legislation. But the existence of such legal measures does not guarantee their application, and most of the time the workers have had to struggle against their managers or local government officials to secure their implementation. They have also at times demanded that mechanisms be established to guarantee their future execution to the collective benefit of workers. This struggle constitutes the backbone of unionization activity in Turkey. Organized labor has always found supporters in Ankara, making lobbying in Ankara or having a connection to the establishment parties a valuable tool in labor struggles, particularly for workers in the public sector.

7 For workers in the private sector, the process took a different shape. Ankara and its political class were always unwilling to enforce the stipulations of the Labor Code in private businesses. It did not possess the necessary means, especially considering the prevalence of small entrepreneurs. The Kemalist one-party government (1925-1945), the direct heir of the Unionist cadres and policies, aimed to encourage the accumulative enterprises of its Muslim citizens, and was therefore always complicit in the transgressions of the Labor Code by the private businesses. Nevertheless, since the bulk of the large industrial establishments were owned by the state, public enterprises did set a minimum standard of conduct for private businesses. The public sector thus became the primary means through which the Kemalist government implemented its social policy, a practice which the Democratic Party inherited virtually unchanged in 1950.

8 Turkish workers were not unfamiliar with grassroots organization. The economic hardships of World War II encouraged them to take initiative. Thus, when unionization was allowed after the war many labor unions were established locally, primarily in the public sector. Many of the influential labor unions of today began as the initiatives of a handful of worker-activists, in few instances encouraged by the local party bosses of the major parties. Whatever their origins were, they developed at later stages in close cooperation with state authorities. After multi-party politics became consolidated, local union bosses and party notables established webs of patronage around labor union locals.

9 The historical disposition of Turkish organized labor made the public enterprises the primary locus of labor union activity. Indeed, minor villages that existed around these establishments often turned into mid-sized cities because of the employment opportunities they created. Moreover, the employees of these establishments constituted the backbone of the membership of the Turkish labor unions. The most important aspect of their existence, though, was the standard they created for the regime's relations to industry. Legislation concerning working conditions, safety measures, social insurances and wages were mainly implemented in public enterprises, which constituted the bulk of the Turkish industry up until the 1980s. The mere presence of these establishments prevented the deterioration of working and living 
conditions in the private sector as well. First, as already noted, organized labor in the public sector provided manpower and a financial basis for the labor unions to operate in private businesses, albeit with differing success. Second, the work environment and safety measures established for the public sector workers set a legal standard that could not simply be violated in the private sector. Last but not least, public sector unions connected politicians in Ankara to labor organizations throughout the country, since public enterprises existed in many Anatolian cities and these workers could potentially influence the polls.

10 The transformation that entered the political agenda in the aftermath of the coup d'état in 1980 threatened the raison d'être of public enterprises as economic institutions with developmental rather than profit-maximizing objectives. The crisis of import substitution made the balance of payments problems insurmountable; thus the problems related to budgetary deficits worsened. When international financial institutions imposed austerity measures on the borrowing countries, the public sector could no longer produce losses for the sake of promoting economic and social development. In this respect, the moral economy argument is useful to describe the seriousness of the change in the industrial relations regime in terms of the total destruction of the populist discourse, if not the actual practices of the regime. The moral economy argument also helps to explain the resistance such changes triggered, a resistance which took the form of direct worker action.

\section{The Moral Economy Argument}

11 The concept of the moral economy was introduced by E. P. Thompson in order to account for English and Welsh food riots that took place during the middle and late 18th century, when the market relations began to permeate provisioning patterns in the countryside (Thompson 1971). Thompson argued that the food riots were not the result of an instinctive impulse - hunger - but rather a legitimate reaction against a new political economy that was not yet perceived as rational and legitimate. James C. Scott, on the other hand, used the term to denote the seemingly non-rational behaviors of Southeast Asian peasants, who constructed the productive relations of their villages around the conception of the right to subsistence of every member of that peasant community (Scott 1979). Scott's study is mainly a debate with the rational choice perspective.

12 The moral economy argument is based on the assumption that economics is shaped by the wider social relations that surround the relations of production and distribution. Therefore, before the construction of the "natural" order of a specific domain of the production relations, there exists another order, which is conceived as natural by a broad segment in any polity. "This in its turn was grounded upon a consistent traditional view of social norms and obligations, of the proper economic functions of several parties within the community, which, taken together, can be said to constitute the moral economy of the poor" (Thompson 1971: 79).

Before Thompson popularized the moral economy argument, the main thread for this line of argumentation came from the seminal work by Karl Polanyi (1986), who introduced the concept of the embeddedness of economic institutions. Polanyi differentiates between modern capitalist economies, which are based on the assumption of the self-regulating market, and traditional economies, where production 
and exchange relationships are embedded in far more comprehensive social and political rules and practices. Polanyi points to the abnormal and manmade nature of the idea of a self-regulating market, and warns about and illustrates the social and economic risks of such institutions. On the basis of these remarks and following in the footsteps of James C. Scott, the term 'moral economy' has become a slogan for the critique of the market economy.

Following Scott, a research agenda emerged where every instance of rebellion against the imposition of the modern economic structures and commercial markets onto traditional polities, especially peasant revolts with a non-capitalist ideological discourse, began to be analyzed in terms of a sharp dichotomy between moral economies and commercial economies. This research program assumes a rift between the so-called self-regulating, autonomous market that permeates all human relations, a process called commodification, and the traditional economies shaped by unchanging social moralities. The moral economy, in this view, belongs to the latter sphere, and is considered a feature of traditional societies. The mainstream scholarly debate thus disregards the conceptualization by Thompson, and focused on morality of market mechanisms and the merit of the assumptions of economic rationality.

Obviously, the moral economy terminology is vulnerable to misuse due to the highly normative connotation of the term. Those who use the term as the antithesis of the 'market economy' in general ignore the capacity of capitalism to preserve non-market social relations as an auxiliary in order to extend its reach over distinct domains of social relationship; consequently, they disregard the cases where resistance against further commodification occurs in an already capitalist society. Latin America, where the superimposition of commercial agriculture over the latifundia holdings did not make wage labor into the norm, is a case in point. The moral economy argument is not only relevant for a traditional form of social relationship; it also entails a specific form of social practice and regulation existing within the capitalist social form, a practice that is distinct from and even opposed to the prevailing market mentality based on a newly institutionalized set of norms and practices. When this latter tries to extend itself onto the "moral economy," in line with the pervasive nature of market structures, the social group victimized by this transformation may resist, even violently, to preserve its pattern of survival.

Thompson used the concept of moral economy to denote the substitution of the existing patriarchal mentality in rural food provisioning practices in Britain and Wales by market relationships. However, he acknowledged the applicability of this term to other fields of study, albeit with extreme caution regarding the transfer of certain concepts to different historical contexts. Indeed, Thompson himself cites the great miner's strike of 1985 against the Thatcher government as one of the last confrontations between the market economy and the moral economy of British workers (Thompson 2006: 424-208). Unlike anthropologically oriented scholars, Thompson does not compare two modes of social relations of production, one traditional and one modern, but rather underlines the possibility that a historically rooted popular consensus on legitimate practices is capable of inspiring resistance when breached by imposed "modern" norms of economic activity. Thus, he is not arguing that market mechanisms are immoral, but that when first introduced they lacked a socially accepted legitimacy. Over time, however, the old moral economy loses its hold over the populace and the rationale of the new political economy takes root. 
17 This is what Thompson conceives as the moral economy, and that is why he cautions against the abuse of the term. It is not difficult to see the relevance of this analysis for understanding every instance where established local patterns of subsistence were threatened by the globalizing system of trade and investment (Calabrese 2005: 309). Other scholars also point in the same direction. For instance, Thomas Clay Arnold points to the cases where the communal ethic of certain social groups or local communities within commercial societies can be an effective base from which to resist prevailing market mechanisms. His example comes from Ovens Valley, California, where the residents were involved in acts of sabotage over rights to ground water. According to him, "The grounds for politically significant moral indignation do not lie only or even predominantly at the level of clashing economies or cultures," but rather "at the intersection of the nested sets of meaning and value called into question by equally specific changes in circumstances" (Arnold 2001: 85). Similar observations were made by a follower of Scott. In a recent study of Vietnamese peasants, Pamela McElwee found a continued resilience of subsistence-oriented attitudes among the village communities in the region where Scott conducted his original research in the 70s (McElwee 2007). This was the case even though agriculture in Vietnam is presently largely commercialized due to successful transformations aimed at the introduction of market institutions.

These cases demonstrate that the moral economy concept is not necessarily useful if the concept is conceived of merely as a moral critique directed against modern market mechanisms from the vantage point of more traditional values. However, the concept becomes more useful when used to account for reactions against the elimination of a mode of subsistence that is considered vital to the maintenance of social ties. According to Arnold, "Moral economy is embedded in concrete ongoing social relations, not in generalized, mechanical moralities or romanticized pasts" (Arnold 2001: 94). A moral economy embodies the main rationale of subsistence of a given polity, and hence is deeply interwoven in culture, so that any threat against it is also threat to the survival of the polity. In such circumstances people tend to organize themselves in order to defend the very basis of the social reproduction of their polities.

This paper argues that the experience of the British miners who resisted the conservative government of Margaret Thatcher to which Thompson refers is roughly comparable to the Turkish workers' mass actions that took place during the late 1980s. Both involved organized resistance by the lower classes demanding that crucial elements of the old arrangement be safeguarded in the face of a thorough transformation of the system that determined their economic and political lot in the regime.

The moral economy argument demonstrates that efforts to preserve the traditional paternalist relationships that provided a safety net for the underprivileged sectors of society during an earlier era are untenable in the face of the structural transformations required by capitalist relations of production. Thompson mentions this point, and Ayșe Buğra made the argument plain in referring to Karl Polanyi's analysis of the Speenhamland system (Buğra 2001: 53). ${ }^{1}$ Similar analyses have been made in different but comparable contexts. For instance, Marsha Pripstein Posusney argues that a moral economy approach is the best possible analytical tool if one wants to make sense of labor unrest in Egypt (Posusney 1993). She asserts that Egyptian workers have resorted to collective action when what they perceive as their entitlements in the Nasserist 
developmental state have been violated by the government or private employers. Although attempting to explain every strike wave or similar unrest by the same rationale is dubious to say the least, she is undoubtedly right in pointing to patronclient relationships between workers and state-builders in the Third World as a factor which contributes to labor activity.

21 Posusney makes another valuable argument on the disposition of the laborers' unrest when triggered because of a perceived violation of the moral economy of the industrial relations. In such circumstances, Posusney asserts, workers' collective action is almost always "restorative" in nature. Rather than demanding a shift in the established mechanisms of industrial relations, the labor movement is inclined to maintain the recognized patterns of interaction between private employers, government and the workers. That is why this type of collective action tends to have limited impact in the long run. One must nevertheless refrain from overgeneralizing specific patterns, and remember that unless the historical path of development of organized labor and its relationship with the state and employers are taken into account, the analysis would turn the moral economy argument into a buzzword describing every instance of collective action by third-world workers.

If it emerges, the restorative collective action pattern can be the consequence of a special kind of relationship between the state and organized labor. In late-developing nations such as Egypt and Turkey, developmentalist aims coupled with a patrimonial political culture may create a particular kind of industrial relations regime where the state, the biggest employer, establishes a bond to the workers under its payroll that can have repercussions for the whole of the working class. In such circumstances organized labor has a stake in maintaining the state-sponsored regime of industrial relations against the uncertainties of a possible thorough transformation. To this end, strategies of resistance may first take the shape of a search for dialogue; if this fails, more direct means may enter the scene. This was the pattern followed in Turkey when civilian rule was restored after the 1980 military intervention, which completely overhauled the legal framework of industrial relations by restricting the right to strike, closing down the radical wing of the Turkish trade unions and erecting legal barriers against unionization activities.

\section{The 1987 Strike Wave and its Aftermath²}

The Türk-iş confederation, the only remaining representative of Turkish organized labor after the 1980 coup, collaborated with the military administration, expecting to benefit from the elimination of its rivals. The confederation headquarters was aware of the enfeeblement of labor unions due to the new legal institutional context that the junta administration established in its effort to transform the Turkish economy from an import-substituting to an export-led form of industrialization. The right to unionize and strike was severely restricted; clauses protecting the employers' profitability were introduced, and direct links between political parties and labor unions were severed. However, the higher echelons of organized labor hoped that once civilian rule was restored, these excesses would be removed (Koç 1989: 95). They were mistaken.

The civilian government led by Turgut Özal did not seek to continue the populist politics of the former center-right cabinets towards the public enterprise labor unions; the military rule might have ended, but the politics of economic liberalization still 
persisted. The structural adjustments that the Turkish system went through did not permit social considerations to be taken into account when formulating economic policies, and the new government taught organized labor the basics of this new era the hard way. For instance, a public employer body was set up to deal with the collective bargaining processes in the public sector, thus severing the patronage link between labor union officials and politicians which previously constituted the basis of labor union activity (Yol-iş 1986: 85-89). Moreover, this body was registered to the Confederation of Turkish Employers' Associations [Türkiye İşveren Sendikaları Konfederasyonu (TISK)]. Petrol-İş, one of the biggest Türk-İş affiliates and the leader of the social-democratic tendency within the confederation, labeled this collaboration a class front of "monopolist capital" "constituted by the government and TísK" against the Turkish working class (Petrol-iş 1987: 7-9). This was not the usual discourse of a labor union organized in publicly owned conglomerates.

Clearly the mood within the labor union circles soured. From early 1987 onwards, the strikes gradually normalized, especially in the industrialized area of greater Istanbul, and took the shape of a minor and localized strike wave. ${ }^{3}$ The first strikes took place in private businesses situated around Istanbul, big metal or chemical factories with a history of labor militancy, such as Netaş, Derby and Dora. These strikes were organized by independent labor unions heir to the militant labor unions of the seventies. However, when Petrol-İs went on strike in sixty-three factories, most of which were private businesses, the intensity of the labor unrest became clear. The Petrol-İş strike involved approximately 20,000 workers, half of whom, the employees of strategic state economic enterprises, did not legally have the right to strike (Petrol-iss 1987: 48, 72). Instead, the latter undertook actions of solidarity, such as silently marching before or after work shifts, boycotting lunch, or spontaneously leaving work and going to the company infirmary together. Needless to say, these actions caused the police to intervene, since some of them amounted to illegal strikes; yet the workers did not surrender. In the summer of 1987, the Zeytinburnu district of Istanbul became another hot spot of labor unrest when Deri-iş went on strike in leather processing businesses, and TÜMTis followed suit in Topkapı warehouses. Finally, when TezKop-iş started a strike in Migros stores, the protest movement became visible even in the wealthy neighborhoods of Istanbul.

The strikes that took place and the labor unions that organized them had some distinguishable common features which allow us to include them under the common umbrella of a strike wave. The majority of these strikes, which mobilized more than twenty-five thousand workers, were organized in private businesses by the more radical labor unions affiliated with Türk-İş. However, except for Petrol-Iss, none of them were influential in the decision-making mechanisms of the confederation, and unlike the majority of the Türk-iş affiliates they were active in private businesses rather than state-owned enterprises. Obviously, the case of Petrol-İs stood alone, since it is one of the biggest labor unions in Turkey, the titular locomotive of the social-democratic opposition in the confederation, and though it was also organized in private businesses, its power base rested in the public sector.

The deteriorating economic conditions which constituted the ostensible motive for the widespread labor unrest was not a novelty in 1987. Real wages had declined steadily since 1979 (Yeldan 2006: 44), and 1987 did not witness a dramatic worsening of these conditions. However, the political agenda of this year was loaded, and that may have 
played a part in the strike wave. The constitutional referendum of 1987 provided a focus for public debate around the country's rights and liberties regime. Organized labor was among the main victims of the limitations imposed on basic political rights, and this was vocally criticized by the leadership of the labor unions from early 1986 onwards. Consequently, labor unions became natural advocates for any political coalition fighting to widen the constricted margins of Turkish democracy.

It must be noted that the 1987 strike wave, however local and politically limited, dispelled the sense of hopelessness in labor union circles and proved the possibility of striking even under the existing laws. As a result, other strikes also took place, in factories such as the State Ware's Office and in the Seydişehir aluminum factory, a giant public enterprise where Türk Metal went on strike for three months due to the low wage offers. General complaints about the conditions of the laborers, aggravated by the unresponsiveness of the government, were the main themes in these labor actions. When the news of the strike in Seydişehir reached him, Özal threatened to shut down the factory, the only producer of aluminum in Turkey, and to liberalize aluminum import. The leader of Türk Metal, Mustafa Özbek, who was known for his docility vis-àvis the employers and the state, reacted furiously, and called Özal a "strike breaker" and “workers' enemy" (Sönmezsoy \& Asliyüce 1989: 279-284).

Such anti-labor-union discourse was not exclusive to the Özal administration. Conservative political movements in other countries have adopted similar strategies in their pursuit of neoliberal transformation. Most famous among them is British prime minister Margaret Thatcher, who, according to Stuart Hall, deployed the discourse of "nation" and "people" against the working class and labor unions with great vigor and popular appeal. Hall argues that this discourse was a purposeful and intentional assault "on the very foundation and raison d'être of organized labor" (Hall 1979: 17). He labels this policy "authoritarian populism."

Other students of British politics, including Bob Jessop, point to the divisive nature of Thatcherist politics. They consider the authoritarian populism argument deficient because it fails to capture the divisive nature of new conservatism, which they see as a strategy to divide the country into, on the one hand, "welfare scavengers," and on the other, members of the middle class with legitimate aspirations for embourgeoisment (Jessop et al. 1984). In a country like England, where class-based political affiliations have an established presence, such political strategies may signify a new phase of class struggle. In Turkey, where the working class was constantly asked to make sacrifices for the sake of national development, and where the national character of this class was stressed in almost every related legal document, the Thatcherist rhetoric constituted an attack on the moral economy of the Turkish workers, and involved a radical break from the populist rhetoric of the political class.

31 The most publicized labor struggle of 1988 took place in SEKA, a monopolistic, strategically important public enterprise located in Kocaeli and the only paper producer in the country. Selüloz-İş, a Türk-Isş affiliate whose membership was primarily from SEKA, had never resorted to a strike in that establishment, and previous governments had generally preferred to protect its qualified workers. The Özal administration, on the other hand, was resolved to maintain its fiscal austerity measures. That is why the negotiations failed, to the surprise of the union officials, who were expecting amelioration in the wages and other social benefits, an expectation shared by the workers on the shop floor. The public employer, mindful of the larger 
collective bargaining stage on the bulk of public enterprises that was to take place in the spring of 1989, did not want the SEKA agreement to exceed certain limits.

Under the leadership of the Kocaeli local of Selüloz-Iş, workers concerned with the lengthening bargaining procedure started passive protests similar to those realized during the Petrol-Isss strikes of the prior year. The government was unimpressed with these protests, and made no concessions to the labor unions' demands; instead, it liberalized paper imports immediately and declared a lockout. The lockout shocked Selüloz-Iş, which faced pressure from the non-unionized staff of SEKA. In order to further discipline the workers, a rumor concerning the relocation of the Kocaeli factory was confirmed by the cabinet. Furthermore, ministers began to point to the low profitability of the establishment. According to their view, wages could only be raised if SEKA's profits rose. This mentality, which placed profitability over the strategic importance of national self-sufficiency in important products, was the hallmark of the Özal administration. For public enterprise labor unionists like those in Selüloz-Iş, who were raised in the context of national developmentalism and state corporatism, these values were foreign. That is why Nevzat Sözer, the general secretary of Selüloz-iş and a former SEKA worker himself, blamed the government: "Those who are responsible for the first strike in SEKA's 54-year long history should be ashamed" (Tarih Vakf1 1998: 6). Sözer, in line with the prevalent mentality among the typical Turkish public enterprise labor unionists, considered the strike in a state-owned establishment an act to be ashamed of, though the real culprit was the government, which blatantly violated the traditional code of industrial relations in state economic enterprises.

\section{The Actions of Spring 1989}

Considering these developments, it would not have been difficult to anticipate that 1989 would be a turbulent year, a repeat of 1987 on a larger scale, since it was the contract renewal year for many public enterprises, a process which would coincide with municipal elections during the first half of the year. Encouraged by the relative success of the preceding years, the labor unions pushed for a deal that would have stopped or even reversed the decline of their members' wages and other social benefits. Furthermore, this time Türk-iş headquarters was able to secure the unity of its affiliates at the bargaining table. It established a central coordination responsible for negotiating with the body representing public employers, and thus coordinated its opposition to the unified front of the employers.

Agreement on the wages and other benefits for 600,000 public workers was blocked by fundamental disagreements. The government did not yield to the demands of the labor unions. Fiscal austerity was the hallmark of the Özal administration, and unless an electoral defeat became imminent, it had little incentive to depart from this principle. On the other side, the unity among the affiliated labor unions was strengthened by the already existing militancy at the shop floor level. The experience of the preceding years had led to the creation of workplace organizations such as strike solidarity committees and committees to monitor the collective bargaining process (Güntepe 1989). These informal organizations emerged as alternatives to outlawed control mechanisms such as strikes and solidarity strikes to ensure the employers' compliance with the terms of existing collective contracts. Furthermore, some labor union leaders preferred representative bodies at the grassroots level to collective bargaining in harsh economic 
conditions without any legal leverage over the employers. The existence of such grassroots organizations thus expanded the unions' organizational structure at the shop floor level.

These grassroots organizations intervened in a bargaining process that seemed to be in a deadlock, and put pressure on the government through newly popularized forms of protest such as lunch boycotts, collectively calling in sick, slowing down production, refusing to shave, shaving off hair, delaying starts of work shifts, and organizing small gatherings and marches before or after shifts. These passive forms of resistance, widely used in recent years to get around legal prohibitions by testing the boundaries of legality, dominated the bargaining process during March and April 1989. They were in fact not entirely new tools in the tool kit of labor protest. ${ }^{4}$ They had not been widely used in the past simply because of the existence of more efficient and active legal ways of protesting. When they occurred in 1989, however, they were spontaneous, widespread, and developed with the initiative of the local labor union activists (Pekin 1989). For instance, in a widely publicized episode from Diyarbakır more than thousand members of Yol-iş petitioned for divorce due to their inability to support their families. This action was truly the first of its kind.

Türk-iş headquarters neither asked for nor sanctioned these actions, yet they formed a formidable moment in a cycle of protest that had started at the end of 1986. Like the Petrol-İs members who defied the ban on striking and supported their comrades by organizing frequent actions of passive disobedience during the collective bargaining process of 1987, and the workers at Kocaeli SEKA factory right before the strike, thousands of public enterprise workers organized spontaneous acts of protest in almost every province of the country. While it is impossible to gauge their precise impact on the negotiations, such actions undoubtedly took part in setting the agenda of the municipal elections, and thus contributed to the governing party's absolute defeat and the eventual agreement between Türk-İş and the government in May. Despite their passive nature, these protests also voiced established political demands of organized labor, such as amendments to the existing laws concerning unionization rights and the collective bargaining regime (Çelik 1996). Moreover, encouraged by the rising labor militancy in the public sector, many strikes followed in the leather processing, metal and chemical industries, most of which continued into 1990.

Türk-Iş headquarters rapidly moved in and supported these local initiatives in order to use them to its advantage in the stalled negotiations. Unlike some of its conservative affiliates, the confederation never hesitated to show solidarity with its members, especially after the municipal elections, which shook the daily routine of the cities every day until the government gave in. The April 1989 issue of the official gazette of Türk-İs is full of articles openly embracing the movements in the street, and a declaration of its presidential council addressed the over-confident government, demanding immediate resolution of the negotiations. Türk-iss sounded like they were among the victors of the municipal elections.

The municipal elections held in March were an utter defeat for Özal's ANAP government, and a promising victory for its main opponent, the left-of-center SocialDemocratic Populist Party [Sosyaldemokrat Halkçı Parti(SHP)]. The urban wage earners seem to have voted for SHP, since it did especially well in the largest industrial cities such as Istanbul, Ankara, Izmir, Adana, Gaziantep and Kocaeli, where the co-occurrence of electoral campaigning with widespread labor unrest and protests had produced a 
political climate largely in favor of labor politics. In addition, the dismal result of ANAP encouraged the workers and facilitated their efforts to obtain an advantageous offer from the official body of public employers. Consequently, an agreement was reached in mid-May between a triumphant şevket Yılmaz, the chairman of Türk-iş, and a governing party losing ground to its opponents. The raise that Türk-iş received brought an increase in real wages for the first time after a decade of decline.

The spring actions marked the first of two climaxes in the cycle of protest that began at the end of 1986 and continued until the last months of 1991 . The sheer number of workers involved in the spontaneous movement can only be compared to such historical incidents in Turkish labor history as the strike wave of 1908 , the unionization thrust in 1946, and the uprising on 15-16 June 1970. Thanks to the spread of the state economic enterprises throughout Anatolia, almost every important city witnessed some form of action. The 1987 strike wave is also important because of its pioneering nature. Despite the authoritarian measures still in force and the general mood of submissiveness inherited from three years of military rule, especially among the ranks of the organized labor movement, these bold attempts by independent labor unions and Türk-iş affiliates broke the silence. The 1989 spring, on the other hand, revealed the anger of the public enterprise workers at being cast out of the political sphere. The accumulated experience of the last two years showed that it was possible to enter the domain of politics using more direct means, which appeared more feasible after the traditional links of dialogue had been severed by the Özal administration. One must acknowledge the passive nature of the protest methods used by the demonstrators, but what appear to be passive actions were in fact invented by the more radical segments of the Turkish organized labor movement in order to bypass the crippling stipulations of the industrial relations regime during the previous years, and when used by thousands of workers on a daily basis they became radical. Under a political regime where every gathering, even scientific conferences, had to obtain authorization from the provincial authorities, "radical" may even be an insufficient adjective to describe the extent to which seemingly passive acts such as marching to workplaces instead of taking service buses or calling in sick collectively challenged the status quo.

The enterprise workers' participation in these acts of civil disobedience was not "spasmodic," to borrow the term from E. P. Thompson. They were not taking the risk of being fired or jailed because they were undernourished or deprived of the means of a decent livelihood. The transgression was not simply against their stomachs, but against the moral economy underpinning their way of making a living. That is why the most crowded demonstrations took place when the labor unions supported such actions and when the main motto of the protest was against the prime minister himself. Their main target was the prime minister, who denounced their labor unions at every opportunity, and wanted to sell off - or worse, close - their work places, openly declaring his allegiance to the employers.

The consequences of the 1989 spring were manifold. First of all, the deal between the government and Türk-Iş ended a decade of permanent decreases in real wages. On the one hand, this must have emboldened the workers in their struggle; on the other hand, it eased the tension, especially among the public enterprise workers. Secondly, the protests of 1989 contributed to the first electoral victory of the left since 1977.1989 also contributed to reducing the harshness of the security forces vis-à-vis public gatherings. From the summer of 1989 onwards the labor unions organized open-air demonstrations 
far more frequently than they had earlier that decade. The workers in the private sector also participated in these demonstrations by organizing solidarity visits or even marches. The strike activity also rose among the private businesses. However, after the signing of the lucrative agreement between Türk-iss and the government, many of the workers who had led these protests were sanctioned by disciplinary investigations and some of them lost their jobs (Oğuz 1995: 50). In most cases labor union officials refrained from protecting these younger grassroots leaders for fear of electoral competition within the unions; in other instances these leaders rose to become officials in various union posts. As expected, the layoffs were more frequent in private businesses. Approximately 6,000 workers were fired during May and June of 1989 in the chemical industry alone. The reports showed that most of these firings were related to the protest movement. In any case, labor union leadership was transformed as a result of the 1989 spring, especially at the local level, though the higher echelons withstood the onslaught, particularly in bigger labor unions. Those who rose to prominence in these actions were eliminated within a few years, yet in the smaller affiliates of Türk-Iss, a new leadership took hold, mostly in close collaboration with left-wing groups.

\section{The Great Miners' March and the Retreat of the Movement}

One of the most illustrative episodes, and the second peak moment in the whole cycle of protest, is the great march of Zonguldak miners to the capital. This experience not only constitutes a model case of the grievances and frustration of the public enterprise workers, but also involves a movement of historical significance. The Zonguldak basin is the foremost coal mining center of the country, yet it never witnessed large-scale labor unrest or even long-lasting strikes. Unlike their counterparts in other countries, the history of Zonguldak miners is devoid of major strikes and demonstrations, apart from the some rare and spontaneous resistance movements. The coal fields in this area were operated from the mid-nineteenth century onwards, by foreign capital during the Ottoman era and by a state monopoly during the Republican era. The first examples of social policy legislation concerning the Zonguldak coal field dates back to the late Ottoman era. Nonetheless, the province has always been geographically and politically isolated from the rest of the country (Roy 1976). Despite the traditional tendency of Turkish labor unions to unite in nationally integrated organizations, Zonguldak miners retained their own labor unions even after the junta passed the Labor Unions Law to promote national unification. All in all, the Turkish Coal Association [Türkiye Taşkömürü Kurumu (TTK)] is a quintessential state economic enterprise and its employees are typical public enterprise workers.

43 From the mid-1980s onwards the Zonguldak mines became the focal point in the debate concerning the privatization policies of the regime. The legal foundations of the privatization program were established in 1984. Turgut Özal never concealed his intentions concerning the state economic enterprises. During his tenure, the public enterprises started to lose their roles as industrial leaders due to the lack of new financial resources (Öniş 1991). Their levels of employment were either frozen or reduced, though their shares in sales and profitability did not decline because of the frequent price adjustments and the public enterprise reform that began with the economic package on 24 January (Waterbury 1992: 136-139). 

Planning Organization, as well as famous industrialists like İshak Alaton, all cited the Zonguldak mines as the primary example of the inefficiency of the public enterprises, claiming that importing coal would be cheaper and more cost-efficient. During his final days as prime minister, Turgut Özal described the Zonguldak mines as a hindrance for the state. According to hum, these institutions operated with higher costs compared to the international standards; hence it was better to shut them down than to renovate them. The major claim of such critics was thus that the coal basin did not operate according to the principles of market rationality. Indeed, the Turkish coal industry had been established on the basis of a different rationale, one based on strategic concerns and the aims of national development. The miners and the populace of Zonguldak were not used to other industrial principles; they had no reason to regard them as relevant for the mines.

urthermore, the demands for higher wages by the labor unions that represented these inefficient institutions were described by Özal as illegitimate. He made plain his stance on these issues when he declared that the state would no longer be a father figure. The newspaper reports show that the miners and general populace of Zonguldak were greatly disturbed by such remarks; their concern was aggravated when the government sold off the mining rights for certain fringe coal veins to private entrepreneurs. It seems that these worries reflected themselves in changes in the Zonguldak Miners' labor union [Genel Maden İşçileri Sendikası (GMis)] leadership after 1986.

GMIS was a typical Türk-iş affiliate prior to 1986, with union bosses who occupied the same posts for years, were heavily involved in local politics through establishment parties, and were used to lobby in Ankara to obtain pay raises and other benefits. At the end of 1986 a new generation of miners was elected to the headquarters of GMis, which unlike many other Türk-Iş labor unions was not located in Ankara but in Zonguldak. The last remnants of the old cadre were swept away in the 1989 congress. A further drive behind this rejuvenation was the unexpectedly negative contract that the old leadership signed during the previous collective bargaining phase. The old leadership's reliance on its connections in Ankara had proven fruitless as the miners' income deteriorated and the TTK lagged behind in technology due to the government's negligence. In addition to these deteriorating conditions came the bombardment of hostile press releases from the authorities. TTK was operating at a loss and was technologically backward, so the union's demands for pay raises were seen as illegitimate. The miners, though, were well aware that it was the government that prevented investment in the coal basin and that wanted to divest the mines to private businesses. They also blamed the government for the decline in their purchasing power and the woes of their province. Anger and frustration was brewing in Zonguldak.

GMiS organized a large demonstration Zonguldak on 24 February 1990 in order to protest an accident that killed sixty-nine miners in the Yeniçeltek lignite mines. Türkİs declared a day of mourning on the same day, but refrained from organizing an openair demonstration in an industrial center to condemn industrial accidents that were claiming the lives of hundreds of workers every year. GMIs, for the first time, was ahead of the confederation. This unusual meeting, accompanied by a two-hour work stoppage, was a sign of the changing mood of Zonguldak miners, who were previously known for their submissiveness. Moreover, the newly elected union administration

European Journal of Turkish Studies, 11 | 2010 
went into the mines and discussed the terms of the contract with the miners, thus adding them to the negotiation process, another novelty for the coal basin.

The public employer seemed to force the labor union to strike by refusing to make monetary offers during much of the negotiations concerning the Institute of Mine Exploration. This attitude was also perceived as proof of the employer's intention to close down the mines. The inhabitants of Zonguldak, whose economy was highly dependent on the mines, watched the bargaining process closely. The miners themselves were involved in the process through the committees that had been established thanks to the supportive approach of the new GMis headquarters. These committees played an important part in the following events. After rumors began circulating that the mines would be closed, the workers, who would normally have demanded wages and benefits, began to demand democracy, in the sense of having a say over the political decisions related to their own futures. ${ }^{5}$ The protest was not restricted to the miners; the entire populace of Zonguldak depended on the mines and wanted its voice heard on a matter so crucial to their livelihood.

As expected, the negotiations collapsed and 42,000 miners went on strike on the last day of November 1990. The uncompromising attitude of the employer strengthened fears that the coal mines would be closed. December of 1990 passed, while the rhetoric about the inefficiency and financial losses of the coal industry intensified, and the grip of the labor union over Zonguldak tightened. Through strike committees the climate of resistance spread everywhere in the province. Türk-isş headquarters intervened in the dealings because of the symbolic character of the crisis. As long as the question of shutting down the coal mines was still on the table, the labor unrest would not calm down, yet the government, pressured by President Özal, did not yield. The confederation thus decided to flex its muscles, and declared a day of action. This day of action was to be, in effect, a general strike. şevket Yılmaz declared that he would not go to work on 3 January 1991, and expected the membership of Türk-Iss to do the same. The participation surpassed expectations, especially in southeastern Turkey, yet the real significance of the action lies in the fact that Türk-Isş resorted to such a radical measure.

The government was not impressed by the confederation's decision to call for a general action, so the negotiations continued to stall the following day. Meanwhile, the miners gathered in Zonguldak city center and waited for the decision of GMis headquarters. From the beginning of the strike, the miners had threatened to march to Ankara, a great march which would finalize the contract for good. Indeed, GMis planned to carry a number of miners to Ankara with buses to further pressure the government to reach a deal. When the buses were not allowed into the city, şemsi Denizer, the relatively young chairman of GMis, invited the miners to march to Ankara on foot (Karakaş 1992). When he and the other officers of GMIs began marching, thousands, including women, followed them without the necessary logistics of a winter march.

51 The sight of ordinary people marching in the winter in the middle of nowhere while chanting slogans against the government was impressive and inspiring to say the least. The procession reached Devrek ${ }^{6}$ at nighttime where the local populace received the marchers extremely well; the next day they reached Mengen ${ }^{7}$ and the lack of logistics began to take a toll. However, the marchers were stubborn and continued for the third day while the government offered to renegotiate the terms of the contract on the condition that they would end the march. The parade arrived a few kilometers away 
from the main highway connecting Istanbul to Ankara before it was halted by a military barricade. The miners camped in front of the fortification for the night. The stalemate was resolved the next day when the prime minister, Yıldırım Akbulut, a mild and traditional politician, disobeyed Turgut Özal and gave his word to şemsi Denizer that the terms of the agreement would be renegotiated.

After the miners returned to Zonguldak, the GMis leadership in Ankara was humiliated, and had to sign a contract that did not match the historical importance of their movement. Türk-iş headquarters, which refrained from organizing active protests in other cities while the miners marched, did not stand by GMIS during this process. This was understandable, since the prime minister's more lenient attitude showed that the imminent threat against the miners' way of living, and hence of the public enterprise workers in general, was beginning to dissolve. However, the militancy of the miners exposed another threat to the established order of the labor unions. The bigger affiliates of Türk-Iss mostly active in public enterprises refrained from organizing widespread solidarity campaigns for the Zonguldak miners since they had achieved beneficial contracts in 1989, and the crusade against public enterprises lost its zeal after ANAP's electoral defeats. In short, with the Özal administration's threat of privatization seemingly alleviated, other labor unions lacked the motivation to support the miners.

The vociferous protest movement of 1989 did not intend to revolutionize the regime of industrial relations, but rather to restore its old basis. That is why there was only limited external support of the miners' march, which threatened to greatly disturb the political status quo of the country. In 1991 the violator of the moral economy was visibly on the decline, and it would lose the general elections a few months later. Largescale privatizations were either postponed or extended. In these circumstances, the establishments of the organized labor movement did not feel the grassroots pressure to intervene directly, hence the activity of the unions receded. This meant, in a sense, the beginning of the retreat of the cycle of protest that had begun in late 1986. Especially during the negotiations of 1991, this retreat became visible just before the ultimate defeat of ANAP in the October 1991 general elections.

1991 marked the end of the cycle of protest instigated by organized labor as a reaction to the neoliberal transformation that threatened the moral economy of the Turkish public enterprise workers who constituted the backbone of the national labor unions. The decline made itself clear in the collective bargaining process of 1991, where a repetition of the protests of 1989 was staged, yet this time in an institutional manner. The spontaneity, creativity, and testing of the limits of the legal system were absent. The principal characteristic of the 1989 spring was the breaking of the routine, yet now these passive forms of action were normalized as auxiliary rituals of the collective bargaining process.

Throughout the negotiations, Türk-Iss headquarters kept the initiative and control over the movement. The content of the slogans was more political in 1991 than in to 1989. This is understandable since everyone expected early general elections, and catchphrases ridiculing Özal were pervasive. For the bulk and the mainstream of the organized labor movement that instigated the popular labor protests after 1986, the target was clearly the transgression of the moral economy. The symbol of this transgression was Özal and his party, whose demise was imminent, not the existing relations of production. In 1991, while the radical phase and upbeat pace of the 
neoliberal transformation process receded, so did its opponent, in the guise of the traditional labor union centers and their membership.

\section{Concluding Remarks}

The reaction against the post-1980 political and economic transformations that aimed to install market rationality based on profit-maximizing behavior as the essential principle in the management of the public economy was mainly defensive in its objectives. Indeed, as already cited, labor unrest triggered because of a perceived violation of the moral economy of industrial relations almost always has a "restorative" disposition. Its restorative nature means that organized labor does not necessarily promote an alternative political agenda for the country; instead, it aims to shield the obvious victims of this transformation, unionized labor in general and employees of the public enterprises in particular, from the consequences of the transformations. The trajectory of development that the Turkish labor movement went through historically involved the higher echelons of Türk-Iss intervening to quell the protests when they breached the limits of acceptable political criticism. A protest movement based on the more lively sectors of the working class opposition, on the other hand, tended to force these limits. If the authorities augmented the political pressures on the opposition, the movement would either give in or radicalize under the rising influence of the politically motivated fringe. However, if the demands were somehow accommodated, the consequence would be the decline of the movement coupled with the emergence of a new balance of forces. The nature of the movement's demands is also an intervening factor: if these were restorative rather than change-oriented, the constitution of a compromise might be reached easier by temporary concessions that did not hurt the basic rationale of the transformation which was under way. This model may summarize the fate of the protest movement instigated by the workers when the Özal administration violated the moral economy of the Turkish organized labor.

Today the turbulent five years spanning from 1986 to 1991 are forgotten. The main reason is the movement's restorative nature and lack of an alternative political agenda. The spring of 1989 and the Great Miners' March are historical moments of a social movement that protested the neoliberal assault on the unionized workers' way of living and broke their daily routines, yet the the movement's lack of a longer-term agenda made them out of touch with the direction of the social change. Furthermore, the Pyrrhic victories which the confederation obtained at the bargaining table with the government protected the workers individually, but also allowed the suppression of their livelihood and nascent culture. That is the very reason why Edward Thompson once remarked it is up to the student of the social history to rescue the meaning of their struggle "from the enormous condescension of posterity." 


\section{BIBLIOGRAPHY}

Arnold, Thomas Clay (2001) "Rethinking Moral Economy", The American Political Science Review 95 (1), pp. 85-95.

Buğra, Ayşe (2001) “Bir Krize ve Bir Ahlaki Ekonominin Çöküşüne Dair”, Birikim, 145, pp. 46-59.

Calabrese, Andrew (2005) “Communication, Global Justice and the Moral Economy”, Global Media and Communication, 1 (3), pp. 301-315.

Çelik, Aziz (1996) “Bahar Eylemleri 1989”, in Türkiye Sendikacılık Ansiklopedisi, vol.1, Istanbul, pp. 103-104.

Granovetter, Mark (1985) "Economic Action and Social Structure: The Problem of Embeddedness", American Journal of Sociology, pp. 481-510.

Güntepe, Ragıp (1989) “Yükselen İşçi Hareketleri Devrimci İşçiler İçin Bir Uyarıdır”, Yeni Çözüm, 24, pp. 5-7.

Hall, Stuart (1979) “The Great Moving Right Show”, Marxism Today 23 (1), pp. 14-20. Jessop, Bob; Bonnett, Kevin; Bromley, Simon; Ling, Tom (1984) “Authoritarian Populism, Two Nations and Thatcherism", New Left Review, 147, pp. 32-60.

Karakaş, Sevkuthan N. (1992) Eylem Günlüğü: Zonguldak Maden Grevi ve Yürüyüşü, Istanbul, Metis. Koç, Yıldırım (1989) Teslimiyetten Mücadeleye Doğru Türk-İş 1980-1989, Istanbul, Amaç Yayınları. McElwee, Pamela (2007) "From the Moral Economy to the World Economy: Revisiting Vietnamese Peasants in a Globalizing Era", Journal of Vietnamese Studies 2, (2), pp. 57-107.

Oğuz, Hasan (1995) 1980 Sonrası İşçi Hareketlerinde Durum, Istanbul, Scala Yayıncılık.

Öniş, Ziya (1991) "The Evolution of Privatization in Turkey: The Institutional Context of PublicEnterprise Reform” International Journal of Middle East Studies 23 (2), pp. 163-176.

Pekin, Faruk (1989) “89 Baharı ve İşçi Eylemleri Üzerine”, Birikim, 2, pp. 19-24.

Petrol-İş (1987) 63 Grev 63 Mücadele, Petrol-İş Yayınları, Istanbul.

Polanyi, Karl (1986) Büyük Dönüşüm Çağımızın Siyasal ve Ekonomik Kökenleri, Istanbul, Alan Yayıncilik.

Pripstein Posusney, Marsha (1993) "Irrational Workers: The Moral Economy of the Labor Protest in Egypt”, World Politics 46 (1), pp. 83-120.

Roy, Delwin A. (1976) “Labour and Trade Unionism in Turkey: The Ereğli Coal Mines”, Middle Eastern Studies, 12 (3), pp. 125-172.

Schamis, Hector E. (1991) "Reconceptualizing Latin American Authoritarianism in the 1970s from Bureaucratic-Authoritarianism to Neoconservatism", Comparative Politics 23 (2), pp. 201-220.

Scott, James C. (1979) The Moral Economy of the Peasant: Rebellion and Subsistence in Southeast Asia, New Haven, Yale University Press.

Sönmezsoy, Refik; Aslıyüce, Erdoğan (1989) Metal İşçilerinin Mücadele Tarihi, Istanbul, Bekaş Yayınları. 
Tarih Vakfı (1998) “SEKA Grev ve Eylemleri, 1988” Türkiye Sendikacıllk Ansiklopedisi, vol. 3, Istanbul, pp. 5-7.

Tarrow, Sydney; Tilly, Charles (2006) Contentious Politics, Boulder CO, Paradigm Press.

Thompson, Edward P. (1971) "The Moral Economy of the Enghlish Crowd in the Eighteenth Century”, Past and Present, 50, pp. 76-136.

Thompson, Edward P. (2006) Avam ve Görenek, İngiltere'de Popüler Kültür Üzerine Araştırmalar, Istanbul, Birikim Yayıncıllk.

Tilly, Charles (2002) "Introduction" in Haimson, Leopold; Tilly, Charles (eds.) Strikes, Wars, and Revolutions in an International Perspective: Strikes Waves in the Late Nineteenth and Early Twentieth Centuries, New York, Cambridge University Press, pp. 433-448.

Türkiye Yol-iş Sendikası (1986) Ekonomik Toplumsal Gelişmeler ve Yol-İş’in Görüşleri, Ankara.

Waterbury, John (1992) "Export-Led Growth and the Center Right Coalition in Turkey", Comparative Politics, 24 (2), pp. 127-145.

Yeldan, Erinç (2006) Küreselleşme Sürecinde Türkiye Ekonomisi Bölüşüm, Birikim ve Büyüme, Istanbul, İletişim Yayınları.

\section{NOTES}

1. Although Buğra's attempt to reduce Thompson's moral economy argument and Polanyi's great transformation thesis to their least common denominator impoverishes the theoretical subtlety of Thompson's argumentation somewhat, it none the less captures the point about the ultimately unsustainable nature of sticking to old forms of paternalism when confronted by new economic and social circumstances.

2. The details of the strikes and other forms of labor resistance cited in this and the following sections are based on the reviews of two monthly newspapers unless otherwise specified. These newspapers are Yeni Çözüm (issues 2-8; 19-31) and İşçilerin Sesi (issues 1-35).

3. Charles Tilly notes that "Strikes differ emphatically from cumulative social phenomena such as births, school attendance and traffic attendance since they veer rapidly in location and number from one period to the next. Indeed strikes arrive in great waves that wash over an entire region or country" (Tilly 2002: 433). The developments of 1987 comply with this pattern.

4. The barefoot marches of the municipality workers from the sixties constitute early examples in this respect.

5. This remark was made by Çetin Uygur, the ex-chairman of Yeraltı Maden-İş and then Dev Maden-Sen, during a personal interview in İstanbul, in 17 May 2009.

6. Devrek is an inland county approximately fifty kilometers south of Zonguldak on the road to Ankara.

7. Mengen is an inland county approximately eighty kilometers south of Zonguldak on the road to Ankara. 


\section{ABSTRACTS}

The 1980s transformed the social and economic outlook of Turkey. This transformation led by the Motherland Party is comparable to the wider global trend of neoliberal transformation. The structural changes necessitated or triggered by this transformation attacked existing modes of social and political relationships, including the moral economy of Turkish unionized workers. The reaction against this assault created a cycle of protest led by the organized labor spanning from the end of 1986 to the fall of 1991 . This protest movement contributed to the electoral defeats suffered by the Motherland Party in 1989 and in 1991. This movement emerged despite repressive legal measures still in force after the military intervention of 1980, and constitutes the last massive showing by the trade unions. This paper analyzes the specifics of the development and the retreat of this social movement.

\section{INDEX}

Keywords: moral economy, neoliberal transformation, trade unions, turkish labor history, turkish politics.

\section{AUTHOR}

\section{MUSTAFA G. DOGAN}

Mustafa Görkem Doğan is a research assistant at the department of Public Administration of the İstanbul University Faculty of Political Sciences from 2000 onwards. He received his B.A. in Politics (2000), M.A. in Modern Turkish History (2003) and Ph. D. in Political Sciences (2010) all from Boğaziçi University. He spent ten months as a visiting researcher at European University Institute in Florence (2005-2006). His research interests include Turkish Political Life, Political and Social Theory, Social Movements and Labor History. gorkemdogan@hotmail.com 